\title{
Genetic linkage between protein and DNA polymorphisms and antioxidant capacity of Cuminum cyminum L. accessions
}

\author{
E. Abdelhaliem ${ }^{1,2}$ and A.A. Al-Huqail ${ }^{2}$ \\ ${ }^{1}$ Plant Molecular Genetic and Cytogenetic, Botany Department, Science College, \\ Zagazig University, Sharkia, Egypt \\ ${ }^{2}$ Botany and Microbiology Department, Science College, King Saud University, \\ Riyadh, Saudi Arabia
}

Corresponding author: E. Abdelhaliem

E-mail: ekram@ksu.edu.sa / ekram.esa@gmail.com

Genet. Mol. Res. 15 (4): gmr. 15048916

Received June 23, 2016

Accepted August 1, 2016

Published October 6, 2016

DOI http://dx.doi.org/10.4238/gmr.15048916

Copyright (C) 2016 The Authors. This is an open-access article distributed under the terms of the Creative Commons Attribution ShareAlike (CC BY-SA) 4.0 License.

\begin{abstract}
This study aimed to link the genetic variation observed using sodium dodecyl sulfate-polyacrylamide gel electrophoresis (SDS-PAGE) and random amplified polymorphic DNA (RAPD) analysis among 11 Cuminum cyminum L. accessions, collected from diverse ecogeographical areas in Saudi Arabia, with their antioxidant capacity to better identify potential genotypes for breeding programs for this medicinal spice. SDS-PAGE analysis revealed genetic variation among cumin germplasms and distinct polymorphisms (100\%). Protein polymorphisms were identified based on the number of polypeptide bands (288) with molecular weights ranging from 13.85 to $350 \mathrm{kDa}$, band intensity, the appearance of new bands, and the absence of other bands. RAPD analysis revealed 363 amplified DNA products with a high polymorphism value (98.88\%) based on DNA band type (unique,
\end{abstract}

Genetics and Molecular Research 15 (4): gmr.15048916 
non-unique, and monomorphic), DNA 90 to 1085-bp long, and band intensity. The unweighted pair group method with arithmetic mean clustering based on SDS-PAGE or RAPD and Jaccard's similarity coefficient divided cumin accessions into similar but distinct clusters with respect to their location of collection. The antioxidant potential of cumin accessions based on 1, 1-diphenyl-2-picrylhydrazyl radical scavenging activity, the $\beta$-carotene-linoleate model system, and total phenolic and flavonoid contents revealed distinct variability. These data indicate that cumin is a valuable genetic resource with high antioxidant activity. Additionally, clustering based on antioxidant activity was not identical to that based on SDS-PAGE and RAPD. Data and clustering of SDS-PAGE and RAPD, combined with the high antioxidant capacity of cumin accessions, are important for the efficient use of genetic resources of cumin in breeding strategies and genetic improvement programs.

Key words: Cuminum cyminum L.; Electrophoretic SDS-PAGE; RAPD-PCR; Polymorphism; Antioxidants; Cluster analysis

\section{INTRODUCTION}

Medicinal spices provide flavor to food, act as preservatives, have health benefits, and provide nutritional benefits. Cuminum cyminum L., known as cumin, is a commonly used spice and the most important economic medicinal spice in Saudi Arabia, cultivated in wide geographical areas in different parts of the country. It is a small annual herbaceous and dicotyledonous plant, is a member of the aromatic plant family Apiaceae with a slender, angular branched stem, and is cultivated as a spice throughout the world (Chaudhary et al., 2014). It is of pharmaceutical and medicinal importance (Bahraminejad et al., 2012). The economic product of this plant is its seed, which has pharmaceutical applications and is used to add flavor to food. Cumin seeds contain numerous phytochemicals that are known to have antioxidant, carminative, and anti-flatulence properties. The active components of cumin may increase the motility of the gastrointestinal tract and enhance digestion. This spice is an excellent source of minerals and contains high levels of B-complex vitamins and other vital anti-oxidant vitamins (Parashar et al., 2014). The seeds are also a rich source of many flavonoid and phenolic anti-oxidants such as carotenes, zeaxanthin, and lutein. Rebey et al. (2012) studied cumin seeds grown in Tunisia and concluded that they contain distinct amounts of phenolic compounds, which show considerable radical scavenging, carotene/linoleic acid chelating, and reducing activities.

Knowledge of the genetic variation of plant germplasm could be an invaluable aid in crop improvement strategies based on allelic variation of genes within a gene pool (Mondini et al., 2009). The introduction of genetic biomarkers has permitted the genetic variability within and among plant germplasm accessions, and within batches of plant samples, to be assessed more efficiently through the use of protein-based biochemical and DNA-based molecular markers that allow more reliable differentiation of genotypes and reveal high levels of polymorphisms. These markers differ with respect to the level of resolution required, locus specificity, genomic abundance, reproducibility, level of polymorphism detected, type of data generated, and technical requirements (Kumar et al., 2009).

Genetics and Molecular Research 15 (4): gmr.15048916 
Characterization of germplasm using seed storage protein-based biochemical fingerprinting can provide a better understanding of genetic affinity of the germplasm and can detect variations in the exon regions (expressed) and in the end products of active structural genes because their sizes and amino acid sequences are the direct results of the nucleotide sequences of these genes (Kumar and Tata, 2010). Hence, any change in the coding sequence of a gene is generally reflected in a corresponding change in the primary structure of the protein. Seed storage proteins can be used to estimate genomic relationships, genetic variation among plant germplasm accessions, and as a tool for crop improvement (Khoshroo et al., 2011). Seed storage proteins are more stable than other plant tissues and are highly polymorphic (Sadia et al., 2009). Sodium dodecyl sulfate polyacrylamide gel electrophoresis (SDS-PAGE) is the most economical, simple, and extensively used biochemical technique to describe seed protein diversity and analyze the genetic structure of crop germplasm. It is considered a practical and reliable method because seed storage proteins are largely unaffected by fluctuations in the environment (Khoshroo et al., 2011). Variation in the protein banding pattern generated by SDS-PAGE can provide information on the relationship among seeds collected from various geographic regions (Singh et al., 2015). Conversely, electrophoretic protein banding profiles are used widely to describe the genetic structure of accessions of wild plant species and are a consistent tool for the economic characterization of germplasm (Pang et al., 2012). Masoumi et al. (2012) evaluated the diversity of seed storage proteins in different cumin, fennel, and longleaf accessions using SDS-PAGE based on seed storage proteins as a biochemical marker.

At the molecular level, genetic variation within and between plant germplasm accessions is assessed using DNA-based molecular fingerprinting, which represents a key development in the field of molecular genetics, is independent of environmental conditions, measures variation in DNA sequences at coding or exon (expressed) and non-coding or intron (non-expressed) regions, and shows high levels of polymorphism (Kumar et al., 2009). Polymerase chain reaction (PCR)-based markers are used to estimate DNA polymorphism, and involves the amplification of DNA sequences using specific or arbitrary oligonucleotide sequences (primers) and a thermostable DNA polymerase (Idrees and Irshad, 2014). The most commonly used DNA-based molecular technique to estimate genetic variation in plants is the random amplified polymorphic DNA based on PCR (RAPD-PCR) because it can detect a relatively large number of randomly amplified DNA loci scattered throughout the entire genome (Kumar et al., 2009). This technique is technically simple, independent of any prior sequence information, has a very high genomic abundance, and requires minimal DNA without the requirement for cloning, sequencing, or any other form of the molecular characterization of the genome (Ghasemi et al., 2014). Additionally, RAPD-PCR markers show high polymorphism, which may arise due to changes in the nucleotide sequence or mutations in the genome loci, making it possible to identify genetic variability between individual organisms or rare or endemic species, and to resolve relationships among populations or germplasm accessions. Studies have shown that the genetic diversity of cumin is high, possibly allowing it to adapt more easily to environmental variations (Bahraminejad et al., 2012). RAPD-PCR is an efficient method used for varietal identification, for the study of polymorphism, genetic biodiversity, and phylogenetic relationships among different plant species (Haliem and Al-Huqail, 2014; Ben Tamarzizt et al., 2015; Sharaf-Eldin et al., 2015), and especially among cumin accessions (Bahraminejad et al., 2012; Rostami-Ahmadvandi et al., 2013; Parashar et al., 2014; Choudhary et al., 2015).

Interestingly, various environmental abiotic stresses lead to the production of reactive

Genetics and Molecular Research 15 (4): gmr.15048916 
oxygen species (ROS) in plants, which are toxic and highly reactive with nucleic acid (DNA and RNA) and proteins resulting in damage to purine and pyrimidine bases, the deoxyribose backbone, and changes in gene expression, as well as abnormal oxidative proteins. Therefore, ROS affect multiple metabolic and physiological processes such as growth, the cell cycle, programmed cell death, abiotic stress responses, pathogen defense, systemic signaling, and development (Sanghera et al., 2013). Conversely, the natural antioxidants present in dietary plants can delay, inhibit, or prevent the oxidation of biomolecules, such as proteins and nucleic acids, and may scavenge free radicals or break the chain reaction due to their redox properties (Dua et al., 2012).

An easy, rapid, and sensitive method used to screen antioxidants in plant extracts involves 1,1-diphenyl-2-picryl hydrazyl (DPPH) used in a free radical scavenging assay, and $\beta$-carotene-linoleate as an inhibitor of lipid peroxidation (Ravindran et al., 2012). The effects of dietary phenolic compounds are of interest due to their antioxidant effects, their ability to hinder oxidative degradation of lipids, and their ability to enhance the nutritional value of food (Srivastava et al., 2013). They also exhibit a wide range of biochemical activities such as antioxidant, antimutagenic, and anticarcinogenic activities, as well as the ability to modify gene expression. Moreover, flavonoids are a group of polyphenolic compounds with distinct properties, which include free radical scavenging, inhibition of hydrolytic and oxidative enzymes and anti-inflammatory action (Srivastava et al., 2013). Additionally, the biological actions of these compounds are related to their antioxidant activity, and they can interfere with the oxidative process by reacting with the chelation of free radicals, catalytic metals, and also by acting as oxygen scavengers (Srivastava et al., 2013). Various herbs and spices, including cumin, have been reported to have antioxidant properties and to exhibit the free radical scavenging activity of ROS (Dua et al., 2012). Rebey et al. (2012) showed that cumin seeds contain high levels of phenolic compounds, which show considerable radical scavenging and carotene/linoleic acid chelating activity and reducing power. In addition, Nadeem and Riaz (2012) concluded that cumin has high antioxidant potential and that this spice can be used to produce novel natural antioxidants as well as flavoring agents that can be used in various food products.

No study has compared genetic variation analyses based on protein and DNA polymorphisms and cumin antioxidant activity. Therefore, the present study aimed to analyze the relative merits of SDS-PAGE and RAPD biomarkers for the evaluation of genetic variation among cumin accessions collected from diverse ecogeographical regions as a basis for germplasm collection and conservation. We also aimed to describe any genetic link between protein and DNA polymorphisms generated by these markers with the antioxidant potential of cumin to determine how and to what extent each cumin accession is resistant to environmental stress in its natural habitats, with high antioxidant activity, to develop breeding strategies for genetic improvement programs of cumin crop.

\section{MATERIAL AND METHODS}

\section{Plant material}

Seeds of 11 cumin accessions were collected from diverse ecogeographical regions in Saudi Arabia and maintained under their related code numbers at the Plant Gene Bank; National Research Centre for Agriculture and Animal Resources (Riyadh, Saudi Arabia) and are listed in Table 1. Viable seeds were screened for uniformity in size, and then divided into two groups. The first group was subjected to SDS-PAGE analysis,

Genetics and Molecular Research 15 (4): gmr.15048916 
and the second group was subjected to RAPD analysis. The use of cumin seeds instead of leaves in this study is of particular interest to botanists and plant ecologists, since it allows accurate estimation of protein and DNA polymorphisms for species that have reduced numbers of leaves or that accumulate staining inhibitors within their leaves, and also for species growing in regions where SDS-PAGE and RAPD techniques are not readily available (Sliwinska et al., 2009).

\section{Table 1. List of 11 cumin (Cuminum cyminum L.) accessions collected from Saudi Arabia and their codes at} the Plant Gene Bank.

\begin{tabular}{l|c}
\hline No. & Accession code \\
\hline 1 & A-48 \\
\hline 2 & A-49 \\
\hline 3 & A-50 \\
\hline 4 & A-124 \\
\hline 5 & A-261 \\
\hline 6 & A-311 \\
\hline 7 & A-374 \\
\hline 8 & A-462 \\
\hline 9 & A-565 \\
\hline 10 & A-575 \\
\hline 11 & A-843 \\
\hline
\end{tabular}

\section{Seed storage protein analysis using SDS-PAGE}

\section{Preparation of seed cake and defatted meal preparation}

After cleaning and washing, individual seeds from 11 cumin accessions were ground into a fine powder to extract the seed storage proteins and defatted according to the method described by Hojilla-Evangelista and Evangelista (2006).

\section{Extraction of proteins}

Proteins were extracted using the method described by Saraswati et al. (1993). Sample buffer was added to $0.2 \mathrm{~g}$ seed flour to form the extraction liquid and mixed thoroughly in an Eppendorf tube by vortexing. The extraction buffer contained the following final concentrations: $0.5 \mathrm{M}$ Tris- $\mathrm{HCl}, \mathrm{pH} 6.8,2.5 \%$ SDS, $5 \%$ urea, and 5\% 2-mercaptoethanol. Before centrifugation at $12,000 \mathrm{~g}$ for $5 \mathrm{~min}$ at $4{ }^{\circ} \mathrm{C}$, the sample buffer was boiled $\left(95^{\circ} \mathrm{C}\right)$ for $5 \mathrm{~min}$.

\section{SDS-PAGE analysis}

SDS-PAGE was performed using a standard method on a vertical slab gel. Bromophenol blue was added to the supernatant as a tracking dye to observe the movement of protein on the gel. Seed storage proteins were analyzed by SDS-PAGE using 10\% polyacrylamide gel (Laemmli, 1970). After electrophoresis, the protein bands were visualized by Coomassie brilliant blue G-250 staining. The polypeptide bands produced in the electropherogram were scored and their molecular weights were estimated by their relative mobilities and compared to the standard Pharmacia protein marker. 


\section{Gel and data analyses}

The protein gel was scanned using a gel documentation system (Advanced American Biotechnology, Fullerton, CA, USA). The bands on each gel lane were counted and compared using a Gel Pro-Analyzer. Quantitative variations in band number, as well as band intensity, were estimated using BIO-RAD video densitometer, Model Gel Doc 2000. With regard to variation in the protein banding pattern, electropherograms of each germplasm accession were scored for the presence (1) or absence (0) of polymorphic polypeptide bands.

\section{Unweighted pair group method with arithmetic mean (UPGMA) clustering dendrogram analysis based on SDS-PAGE database}

Cluster analysis was conducted based on SDS-PAGE data, and Jaccard's similarity coefficient estimates by the UPGMA was used to indicate the genetic relationships among the cumin germplasm accessions. Consequently, the presence or absence of polypeptide bands, molecular weights, band numbers, and band intensities were used as approximate values to estimate genetic relationships in the dendrogram.

\section{DNA isolation and the RAPD-PCR technique}

\section{Isolation of genomic DNA}

Genomic DNA was isolated from cumin seeds using a modified hexadecyl trimethyl ammonium bromide assay (Kit and Chandran, 2010).

\section{Quantity and quality of isolated DNA}

The DNA yield was measured using a NanoDrop ${ }^{\mathrm{TM}} 1000$ spectrophotometer (Thermo Scientific, Waltham, MA, USA) at $260 \mathrm{~nm}$. DNA purity was determined by calculating the absorbance ratio at $\mathrm{A}_{260 / 280} \mathrm{~nm}$. Polysaccharide contamination was assessed by calculating the

absorbance ratio at $\mathrm{A}_{260 / 230} \mathrm{~nm}$ (Wilson and Walker, 2005). For quality and yield assessments, electrophoresis was performed for all DNA samples on $0.8 \%$ agarose gels, and the gels were stained with ethidium bromide; the bands were observed in a gel documentation system (Advanced American Biotechnology, Fullerton, CA, USA) and compared with those from a known standard lambda DNA marker.

\section{PCR amplification of purified DNA samples using random RAPD primers}

The PCR mixture contained $2.5 \mu \mathrm{L} 10 \mathrm{X}$ buffer and $15 \mathrm{mM} \mathrm{MgCl}_{2}$ (Fermentas), with $0.25 \mathrm{mM}$ each dNTP (Sigma), $0.3 \mu \mathrm{M}$ primer, $0.5 \mathrm{U}$ Taq DNA polymerase (Sigma), and 50 ng template DNA. PCR was performed in a Palm Cycler (Corbett Research) using the following profile with an initial denaturation of $4 \mathrm{~min}$ at $95^{\circ} \mathrm{C}$ followed by 40 cycles of $1 \mathrm{~min}$ at $95^{\circ} \mathrm{C}, 1 \mathrm{~min}$ at $38^{\circ} \mathrm{C}$, and $2 \mathrm{~min}$ at $72^{\circ} \mathrm{C}$, with a final extension at $72^{\circ} \mathrm{C}$ for $10 \mathrm{~min}$, and a hold temperature of $4^{\circ} \mathrm{C}$ at the end. Twenty primers (Thermo Scientific) for RAPD analysis were independently selected to amplify the DNA samples in the PCR (UBC, University of British Columbia, Canada) following the method of Williams et al. (1990) with some modifications. 
Only six decamer oligonucleotide primers (P- 03, 05, 07, 09, 14, and 18) successfully amplified reproducible DNA products. For DNA amplification, PCR was run for 35 cycles, which consisted of a denaturation step $\left(1 \mathrm{~min}\right.$ at $\left.95^{\circ} \mathrm{C}\right)$, annealing step $\left(1 \mathrm{~min}\right.$ at $\left.35^{\circ} \mathrm{C}\right)$, and elongation step $\left(2 \mathrm{~min}\right.$ at $\left.72^{\circ} \mathrm{C}\right)$. After 34 cycles, a final extension period was added ( $5 \mathrm{~min}$ at $72^{\circ} \mathrm{C}$ ). The amplification products were electrophoresed on $1.5 \%$ agarose gel (Sigma) in TAE buffer $(0.04 \mathrm{M}$ Tris-acetate, $1 \mathrm{Mm}$ EDTA, $\mathrm{pH} 8)$. The run was performed at $100 \mathrm{~V}$ for $1 \mathrm{~h}$. Gels were stained with $0.2 \mathrm{mg} / \mathrm{mL}$ ethidium bromide for $15 \mathrm{~min}$. The PCR products were visualized under a UV light transilluminator. A 100-bp DNA ladder (Gibco-BRL, USA) was used as the DNA size marker and loaded into the first lane of each gel to evaluate band size. Bands on the gel were detected on UV-transilluminator and photographed using a Polaroid camera.

\section{DNA band scoring and data analysis}

Following the separation of PCR products by agarose gel electrophoresis, gels were visualized with Photo Print (Vilber Lourmat, France) imaging system and digitized RAPD fingerprints were analyzed using one-dimensional software (Advanced American Biotechnology and Imaging, Fullerton CA 92831, USA) based on the number of polymorphic (unique and nonunique DNA bands), and monomorphic DNA bands, and the molecular sizes of bands as well as band intensities for each cumin accession. Amplified DNA products for RAPD analysis were scored based on the presence (1) or absence (0) of a DNA band for each primer.

\section{UPGMA clustering dendrogram analysis based on a RAPD database}

RAPD data were entered as into a binary data matrix as discrete variables. Jaccard's coefficient of similarity was measured and a dendrogram based on RAPD data and the genetic similarities matrix was generated by using UPGMA. Consequently, the presence or absence of DNA bands, their molecular sizes, numbers, and optical intensities were used to estimate genetic relationships in the dendrogram.

\section{Antioxidant capacity assays}

Powdered cumin seeds of each accession were extracted with methanol solvents by Soxhlet extraction for $6 \mathrm{~h}$ according to the method described by Lim et al. (2002). The extracts were combined, filtered, and evaporated to dryness under reduced pressure at $60^{\circ} \mathrm{C}$ by a rotary evaporator. Extracts were placed in a dark bottle, and stored at $-8^{\circ} \mathrm{C}$ until further analyses. The antioxidant potential of cumin seeds was analyzed employing various in vitro assay systems, a DPPH free-radical scavenging assay, and the $\beta$-carotene-linoleate model system, in addition to determination of total phenolic and flavonoid contents, to test the antioxidant activities of the extracts.

\section{Scavenging activity on DPPH radicals and the $\beta$-carotene-linoleate model system}

The antioxidant activity of cumin samples and standards was determined by the free radical scavenging activity method using DPPH in addition to the $\beta$-carotene-linoleate model system for inhibition of lipid peroxidation. Both methods were previously described by Haliem and Al-Huqail (2014).

Genetics and Molecular Research 15 (4): gmr.15048916 


\section{Total phenolic and flavonoid contents}

Total soluble phenolic content was determined using the Folin-Ciocalteu method and estimated for each extract as described by Ravindran and Naveenan (2011). Gallic acid was used as the phenolic standard. The concentration of total phenol compounds was calculated using a standard curve of gallic acid equivalents and expressed as microgram per milligram of dry weight. Conversely, total flavonoid content was determined using aluminum chloride based on the methods described by Zhishen et al. (1999), with modifications as required. The results are reported as micrograms of quercetin equivalents per milligram of dry weight.

\section{UPGMA clustering dendrogram analyses based on antioxidant data}

Three replicates $(\mathrm{N}=3)$ of each cumin accession were used for statistical analyses of antioxidant potential. Data are reported as means \pm SD. For cluster analysis, variables were standardized using the PAST computer program, similarity matrices were generated, and the dendrogram was constructed using UPGMA to indicate relationships among the cumin accessions, based on the obtained antioxidant capacity data.

\section{RESULTS}

\section{SDS-PAGE analysis}

\section{Electrophoretic seed storage protein polymorphism}

In this study, electrophoretic polypeptide banding patterns generated by SDS-PAGE were investigated to determine genetic variation among 11 cumin germplasm accessions. These patterns varied quantitatively and qualitatively among different accessions (Table 2 and Figure 1). A total of 288 polypeptides bands with different molecular weights ranging from 13.85 to $350 \mathrm{kDa}$ were revealed, of which 158 bands represented polymorphic loci, including 81 unique polypeptide loci with a value of $28.13 \%$ plus 77 non-unique loci with value of $26.74 \%$. The level of protein polymorphism observed by SDS-PAGE was very high, and reached $100 \%$ based on the molecular weight $(\mathrm{kDa})$ of polypeptide bands and their fractionation, type (unique, non-unique, and monomorphic bands), band number, band intensity, appearance of new bands (unique loci), and absence (non-unique loci). The maximum number of polypeptide bands ( 30 bands) was found in accession A-50 of cumin germplasm, with a value $10.42 \%$ and molecular weights ranging from 15.01 to 350 $\mathrm{kDa}$, while the lowest number of polypeptide bands (23) was found in accession A-48 of cumin germplasm with a value of $7.99 \%$ and molecular weights ranging from 15.01 to $350.00 \mathrm{kDa}$. Conversely, SDS-PAGE revealed that 81 polypeptide unique bands among 11 cumin accessions varied in number, molecular weight $(\mathrm{kDa})$, and band intensity (Table 2 ). The highest number of unique polypeptides bands was 12 , with a value of $14.82 \%$ scored for two cumin germplasm accessions, A-261 and A-843, while the lowest number of unique polypeptides bands was two, with a value of $2.47 \%$ scored for cumin germplasm accession A-124.

Genetics and Molecular Research 15 (4): gmr.15048916 


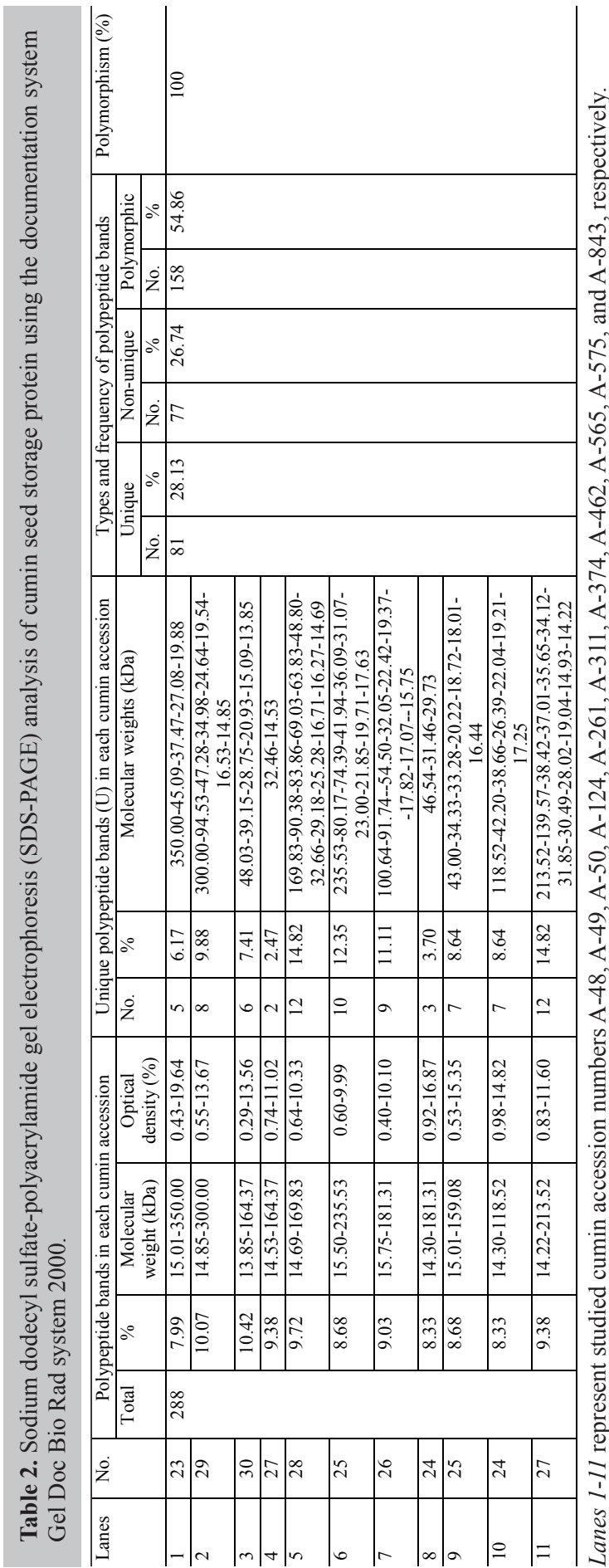

Genetics and Molecular Research 15 (4): gmr.15048916 


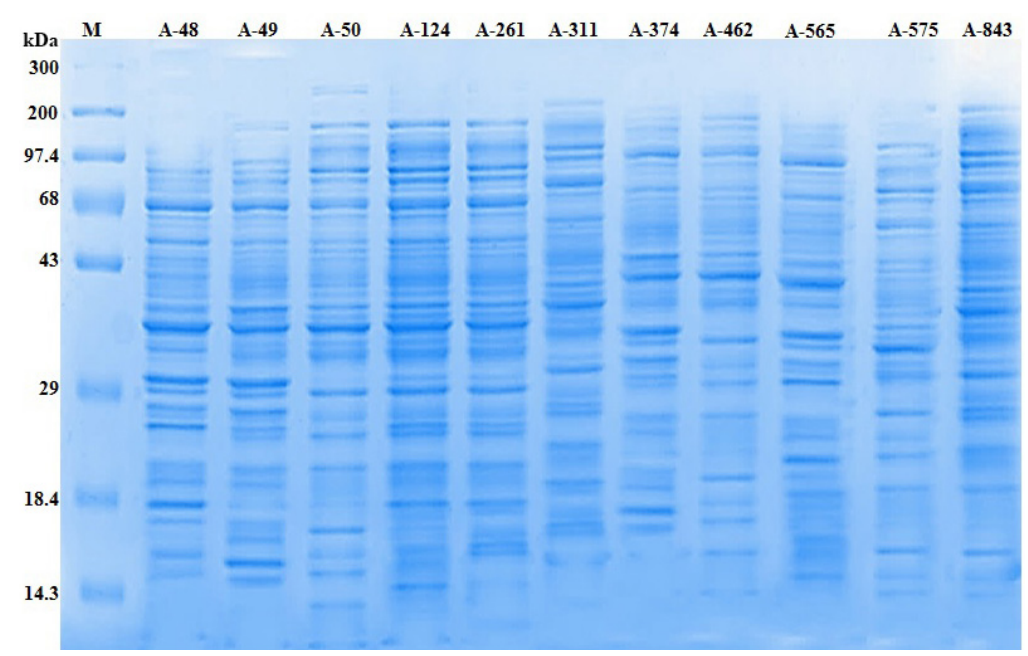

Figure 1. Polypeptide banding pattern of studied cumin (Cuminum cyminum L.) accessions obtained by sodium dodecyl sulfate-polyacrylamide gel electrophoresis (SDS-PAGE) analysis. Lanes represent individual cumin accessions. Lane $M$ is the standard protein marker.

\section{Cluster analysis based on SDS-PAGE data}

Clustering based on the profiles of seed storage proteins provides information on the phylogenetic relationships of genotypes of cumin germplasm accessions. The UPGMA clustering dendrogram was consistent with their genetic similarity based on the SDS-PAGE data, and the distance matrix exhibited two major clusters, (I) and (II) (Figure 2). The first cluster (I) was divided into two sub-clusters, (i) and (ii); sub-cluster (i) included only one cumin germplasm accession, A-843, while sub-cluster (ii) included two cumin germplasm accessions, A-575 and A-48. Conversely, the second cluster (II) was divided into two subclusters, (iii) and (iv); sub-cluster (iii) contained two cumin germplasm accessions, A-565 and A-49, while sub-cluster (iv) included two groups, 1 and 2. Group 1 contained two clades, (a) and (b). Clades (a) had two sub-clades, (c) and (b); sub-clade (c) included two cumin germplasm accessions, A-462 and A-374, and linkage with a cumin germplasm accession in sub-cluster (iii) of cluster (II), while sub-clade (c) contained one cumin germplasm accession, A-124, separately. Clade (b) included two cumin germplasm accessions, A-311 and A-50. Furthermore, group 2 contained one cumin germplasm accession, A-261, which was separated from the other five accessions of group 1.

\section{DNA-marker analysis using RAPD}

\section{RAPD polymorphisms}

Of the 20 primers used to assess genetic variation among 11 germplasm accessions of cumin using the RAPD-PCR technique, six were found to be amplified or reproducible. The codes and sequences of these primers were listed in Table 3. These six primers amplified 375 DNA bands or fragments, with an average of 62.5 bands per primer, which varied in specific random sequences, band intensity, and size, ranging from 88 to $1100 \mathrm{bp}$, and the type of DNA

Genetics and Molecular Research 15 (4): gmr.15048916 
bands (Table 3 and Figure 3). DNA polymorphism values produced by highly polymorphic primers ranged from $90.91 \%$ with primer- 05 , to $100 \%$ with primers $\mathrm{P}-07, \mathrm{P}-09, \mathrm{P}-14$, and $\mathrm{P}-18$ based on the absence or presence of monomorphic bands. Of the 375 DNA bands scored, 182 (48.53\%) represented polymorphic bands, including 103 unique loci with value of $27.47 \%$, plus 79 non-unique loci with a value of $21.07 \%$, as well as two monomorphic bands with a value of $0.53 \%$, which were generated by two primers (P-03 and P-05). The maximum number of DNA bands generated by six primers was 38 with a value of $10.13 \%$ scored in cumin accession A-48, while A-575 scored the lowest number of DNA bands (30) at a value of $8.00 \%$. Primer- 18 amplified the highest number of bands (98) with a value of $26.13 \%$, while primer-05 amplified the lowest number of bands (24) with a value of $6.40 \%$.

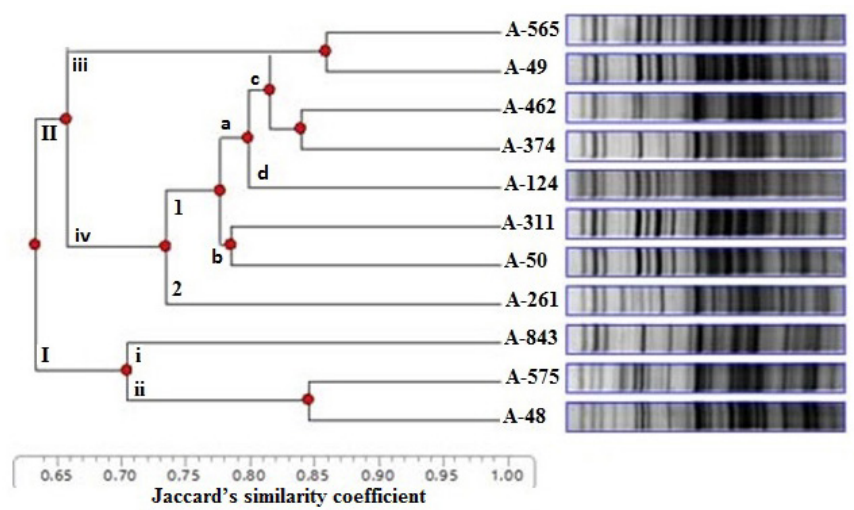

Figure 2. Dendrogram representing the genetic relationship between studied cumin accessions as revealed by the unweighted pair group method with arithmetic mean (UPGMA) clustering based on SDS-PAGE database analysis.

RAPD analysis revealed 103 amplified unique DNA bands among 11 cumin accessions, which varied in number, DNA size, and intensity (Table 4). The maximum number of unique polypeptides bands was 20 , with a value of $19.42 \%$, scored for the cumin germplasm accession A-843. Conversely, the minimum number of unique polypeptide bands was four, with a value of $3.88 \%$ scored for two cumin germplasm accessions, A-49 and A-374.

\section{Cluster analysis based on RAPD data}

The UPGMA clustering dendrogram based on RAPD data and the distance matrix produced two major clusters, (I) and (II) (Figure 4). The first cluster (I) was divided into two subclusters, (i) and (ii); sub-cluster (i) included two cumin germplasm accessions, A-261 and A-843, while sub-cluster (ii) included two cumin germplasm accessions, A-50 and A-575. Conversely, the second cluster (II) was divided into three sub-clusters, (iii), (iv), and (v); sub-cluster (iii) included two groups, (a) and (b). Group (a) contained one cumin germplasm accession, A-462, which was separated from the two cumin germplasm accessions, A-374 and A-124 of group (b). Sub-cluster (iv) included two groups, (c) and (d). Group (c) contained two cumin germplasm accessions, A-565 and A-311, while group (d) contained one cumin germplasm accession, A-49, which was separated from the two cumin germplasm accessions of group (c).

Sub-cluster (v) included one cumin germplasm accession, A-48, which was completely separate from the cumin germplasm accessions in sub-clusters (iii) and (iv).

Genetics and Molecular Research 15 (4): gmr.15048916 
E. Abdelhaliem and A.A. Al-Huqail

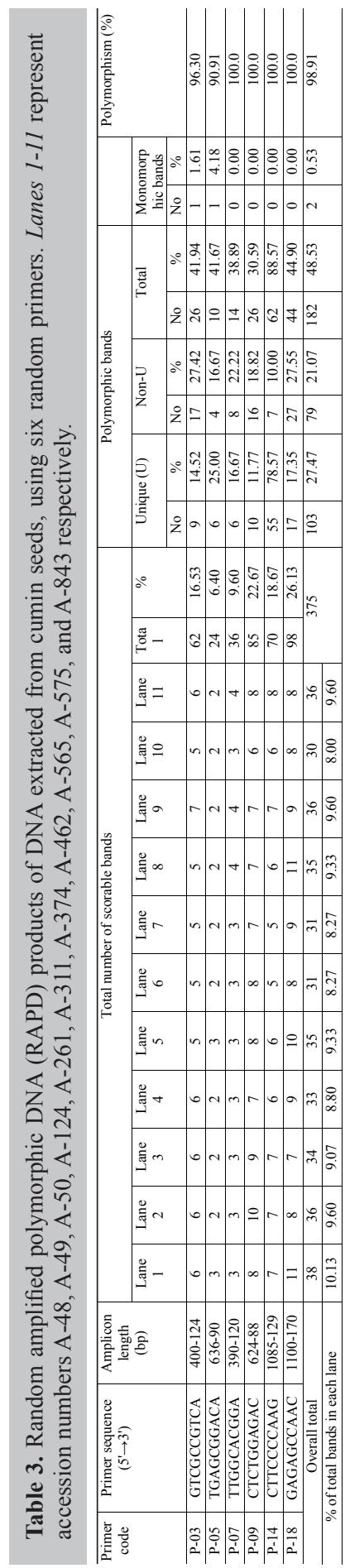

Genetics and Molecular Research 15 (4): gmr.15048916 

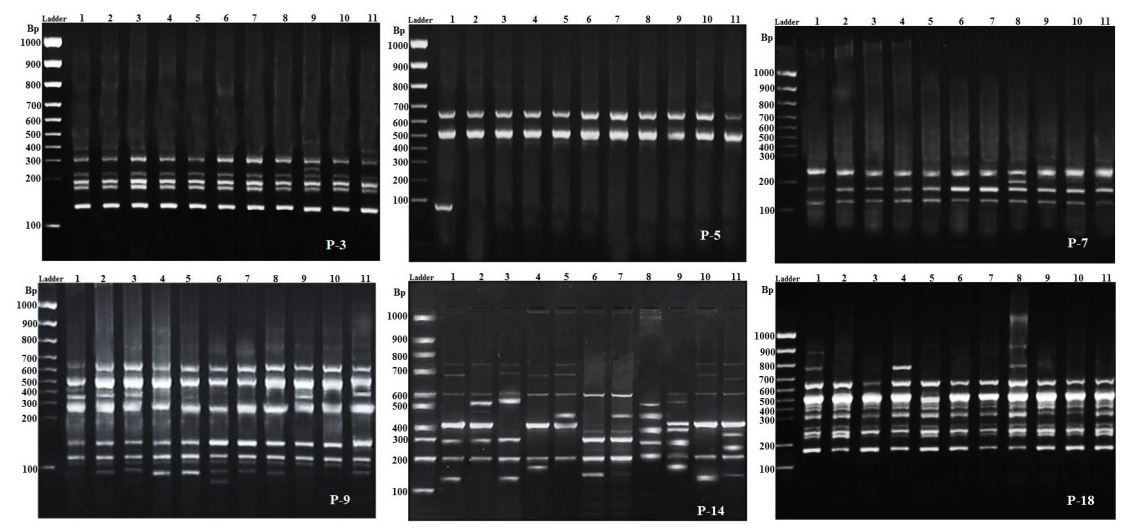

Figure 3. Random amplified polymorphic DNA (RAPD) products from amplified DNA fragments extracted from seeds of cumin accessions using six primers (P-03,05,07,09,14, and 18). Lanes 1-11 represent the germplasm accessions A-48, A-49, A-50, A-124, A-261, A-311, A-374, A-462, A-565, A-575, and A-843, respectively. Lane $M=100$-bp DNA marker.

\section{Antioxidant capacity assays}

The antioxidant potential of cumin seeds was analyzed employing various in vitro assay systems, including the hydroxyl radicals/hydrogen peroxide/DPPH radical scavenging assay and inhibition of lipid peroxidation using the $\beta$-carotene-linoleate model system, in addition to the determination of total phenolic and flavonoid contents (Table 5). Those antioxidant assays revealed distinct variability in antioxidant capacity among 11 cumin accessions. Cumin accession A-48 exhibited the highest DPPH radical scavenging activity and antioxidant activity of $\beta$-carotene-linoleate, and had the highest total flavonoid content, reaching $38.04 \pm 0.03 \%$, $44.45 \pm 2.10 \%$, and $77.61 \pm 2.01 \mathrm{mg} / \mathrm{mg}$, respectively. Conversely, cumin accession A-575 exhibited the lowest DPPH radical scavenging activity and antioxidant activity of $\beta$ - carotenelinoleate, at $29.61 \pm 2.30$ and $31.05 \pm 2.4 \%$, respectively. This accession also had the highest phenolic content, reaching $34.79 \pm 0.03 \mathrm{mg} / \mathrm{mg}$. In contrast, cumin accession A-462 had the lowest phenolic and flavonoid content, at $28.19 \pm 0.04$ and $68.19 \pm 1.30 \mathrm{mg} / \mathrm{mg}$, respectively.

\section{Cluster analysis based on antioxidant potential}

The UPGMA clustering dendrogram based on the antioxidant activity and distance matrix produced two major clusters, (I) and (II) (Figure 5). Cluster (I) included cumin accession A-48, which was completely separate from the other 10 cumin accessions in the second cluster, (II). In contrast, cluster (II) was divided into two sub-clusters, (i) and (ii); sub-cluster (i) included two cumin germplasm accessions, A-49 and A-843, while sub-cluster (ii) was divided into two groups, (A) and (B). Group (A) contained one cumin germplasm accession, A-575, which was completely separated from the seven cumin germplasm accessions in group (B) and included two subgroups, (1) and (2). Subgroup (1) contained two cumin germplasm accessions, A-374 and A-462, while subgroup (2) was divided into two clades, (a) and (b). Clade (a) contained only cumin germplasm accession A-261, while clade (b) was divided into two sub-clades, (c) and (d). Sub-clade (c) included two cumin germplasm accessions, A-65 and A-311, and sub-clade (d) contained two cumin germplasm accessions, A-50 and A-124.

Genetics and Molecular Research 15 (4): gmr.15048916 
E. Abdelhaliem and A.A. Al-Huqail

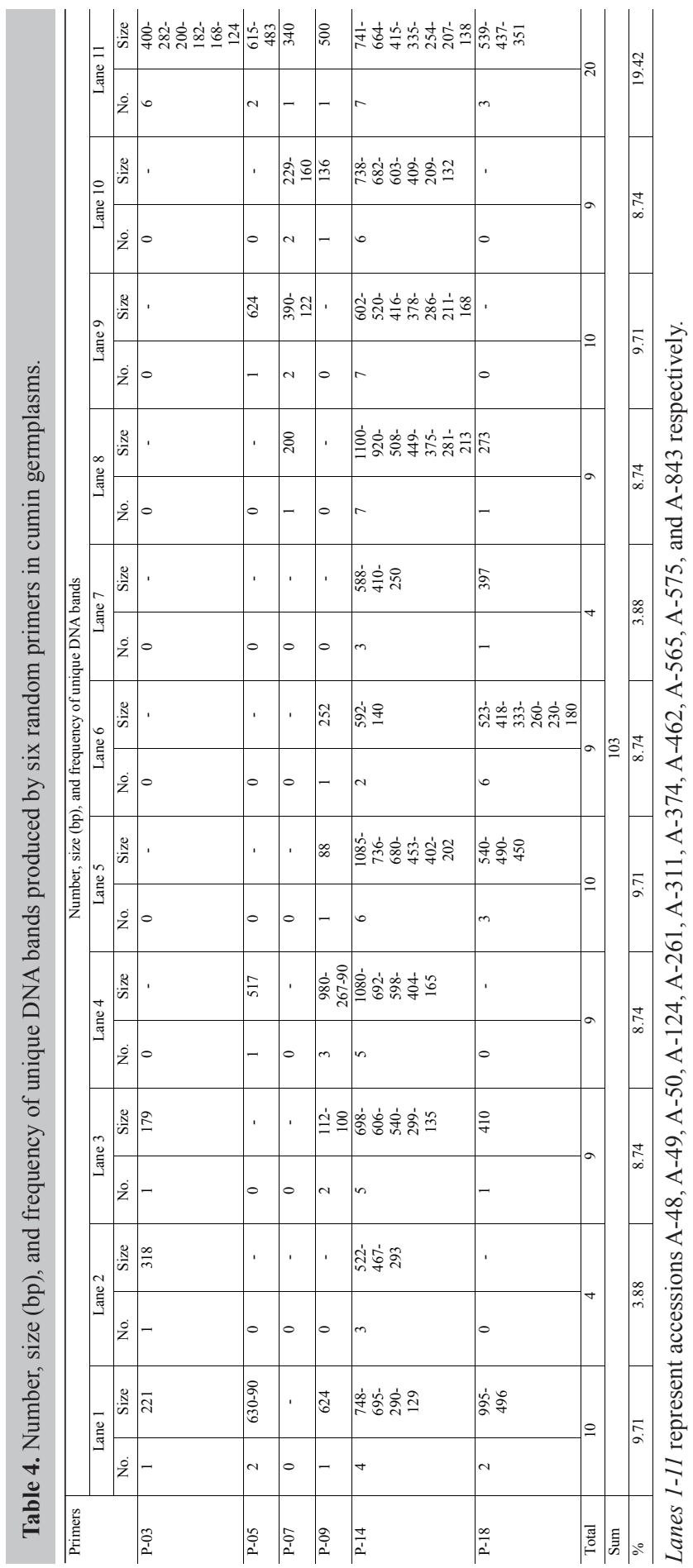

Genetics and Molecular Research 15 (4): gmr.15048916 


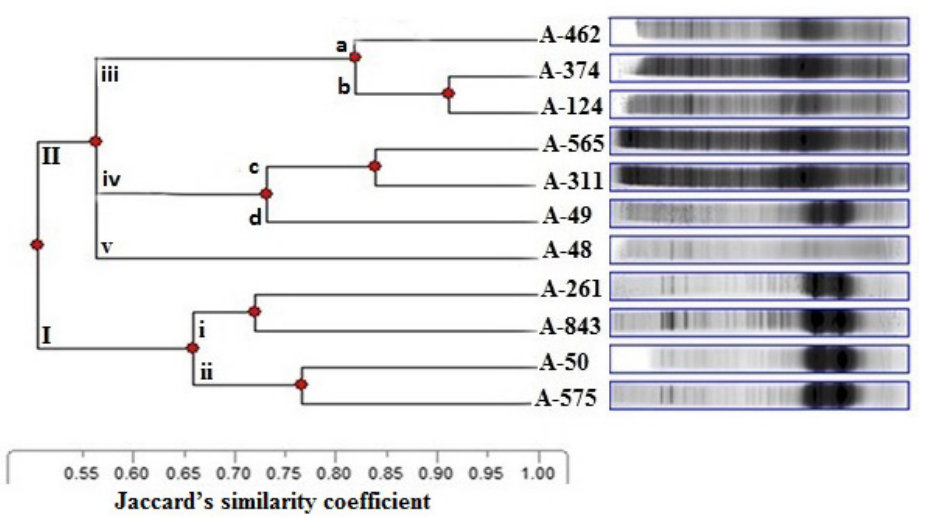

Figure 4. Dendrogram representing genetic relationships between studied cumin accessions as revealed by UPGMA clustering based on six primers of an RAPD database analysis.

Table 5. Antioxidant capacity, total phenolic and flavonoid contents of cumin seed extracts, with values reported as means $\pm \mathrm{SD}(\mathrm{N}=3)$.

\begin{tabular}{l|c|c|c|c}
\hline \multirow{2}{*}{ Accessions } & \multicolumn{4}{|c}{ Parameters of antioxidant activity } \\
\cline { 2 - 5 } & \% of DPPH scavenging & \% of $\beta$-carotene antioxidant activity & Phenol content $(\mathrm{GAE} \mu \mathrm{g} / \mathrm{mg})$ & Flavonoid content $(\mathrm{QE} \mu \mathrm{g} / \mathrm{mg})$ \\
\hline A-48 & $38.04 \pm 0.03$ & $44.45 \pm 2.10$ & $28.64 \pm 0.02$ & $77.61 \pm 2.01$ \\
\hline A-49 & $33.16 \pm 0.04$ & $34.95 \pm 1.20$ & $30.19 \pm 0.06$ & $75.41 \pm 1.60$ \\
\hline A-50 & $33.16 \pm 0.21$ & $39.52 \pm 2.30$ & $28.46 \pm 0.03$ & $72.14 \pm 2.30$ \\
\hline A-124 & $31.50 \pm 2.30$ & $39.91 \pm 2.30$ & $31.34 \pm 0.02$ & $72.54 \pm 3.5$ \\
\hline A-261 & $34.27 \pm 3.2$ & $37.18 \pm 3.20$ & $30.17 \pm 0.03$ & $70.55 \pm 1.30$ \\
\hline A-311 & $35.08 \pm 2.1$ & $42.01 \pm 2.30$ & $28.36 \pm 0.23$ & $71.09 \pm 1.12$ \\
\hline A-374 & $34.97 \pm 1.15$ & $40.35 \pm 2.80$ & $33.49 \pm 0.13$ & $68.19 \pm 1.30$ \\
\hline A-462 & $31.05 \pm 0.47$ & $37.59 \pm 1.30$ & $28.19 \pm 0.04$ & $69.14 \pm 2.30$ \\
\hline A-565 & $32.21 \pm 0.21$ & $37.51 \pm 2.10$ & $29.46 \pm 0.05$ & $71.26 \pm 1.10$ \\
\hline A-575 & $29.61 \pm 2.30$ & $31.05 \pm 2.4$ & $34.79 \pm 0.03$ & $77.05 \pm 1.50$ \\
\hline A-843 & $33.46 \pm 1.10$ & $42.39 \pm 1.80$ & $33.29 \pm 0.13$ & \\
\hline
\end{tabular}

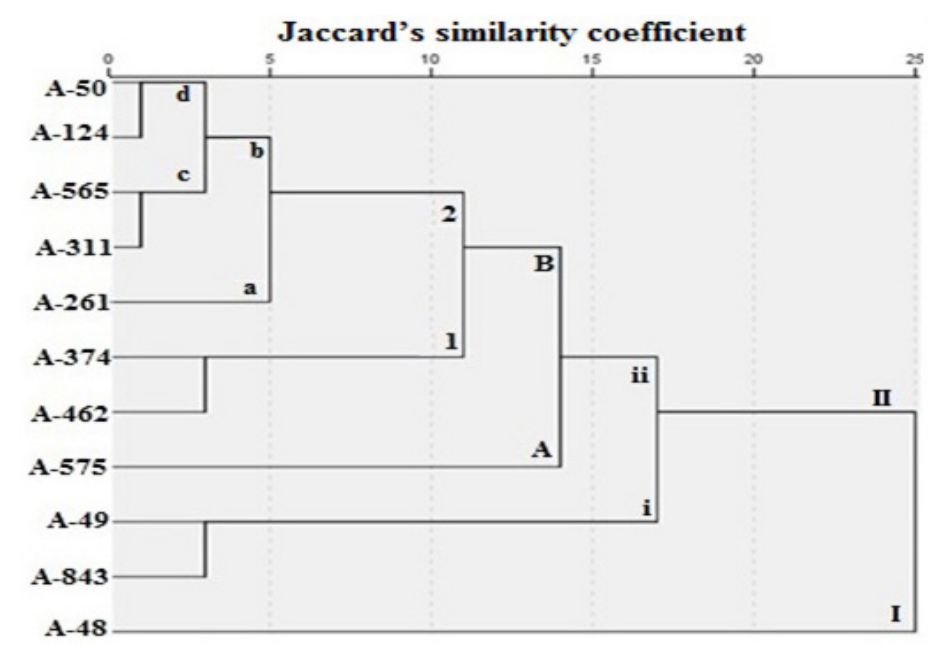

Figure 5. Dendogram representing relationships between studied cumin accessions as revealed by UPGMA clustering based on the antioxidant capacity data.

Genetics and Molecular Research 15 (4): gmr.15048916 


\section{DISCUSSION}

Protein banding patterns generated by SDS-PAGE revealed the presence of genetic variation among 11 cumin (C. cyminum L.) germplasm accessions based on molecular weight, staining intensity, band number, new polypeptide bands (unique bands), and absence of other polypeptide bands (non-unique bands). This has led to high levels of protein polymorphism, helping to distinguish cumin germplasms at specific levels. This level of protein polymorphism revealed by SDS-PAGE confirmed that this biomarker has the ability to reveal high levels of intra-specific genetic variation among seed storage proteins of cumin accessions based on their geographic distribution. Conversely, the electrophoretic polypeptide banding patterns revealed variabilities among cumin accessions that may provide genetic specificity for each accession; this because proteins represent the final products of gene expression of active structural genes and hence, any change in the coding sequence of a gene is generally reflected in a corresponding change in the primary structure of the protein (Sadia et al., 2009).

Additionally, variation in protein banding profiles may provide information on the relationship between cumin seeds collected from various geographic regions; therefore, these are a promising tool for the determination of protein polymorphism. Protein polymorphisms observed among cumin accessions may arise as a result of changes in the nucleotides of a coding sequence of DNA, which may lead to a change within the amino acid sequence of a protein, such as the addition, insertion, or deletion of amino acids in the polypeptide chain due to specific abiotic stresses that occur in their different geographical regions (Galani et al., 2011). Therefore, protein polymorphisms may serve as genetic biomarkers because their variability is generally highly heritable in the exon regions of genome, and can be highly polymorphic. |The appearance of new bands (unique bands) can be considered as a characteristic biomarker assay specific for each cumin germplasm, which usually results from changes in the structure of DNA (e.g., insertion or deletion of DNA fragments of various lengths, breaks, transpositions), which leads to changes in the amino acids that form the protein (Mondini et al., 2009).

The development and use of DNA-based molecular markers to detect and exploit DNA polymorphism is one of the most significant developments in the field of molecular genetics. RAPD analysis was shown to be a very sensitive tool for screening changes in nucleotide sequence polymorphisms among cumin accessions in any region of their genome (introns, exons, and regulation regions) (Mondini et al., 2009). This marker exhibited distinct qualitative and quantitative differences (polymorphisms) within the nucleic sequence of each C. cyminum germplasm based on the number of gene products, the size of the amplified DNA fragment, band intensities, and the appearance of new DNA bands (unique bands), or the disappearance of other bands (non-unique bands), leading to high levels of DNA polymorphism. These techniques generate a specific profile for each of the cumin accessions, thus allowing them to be differentiated from each other genetically.

DNA polymorphisms are produced by rearrangements or deletions at or between oligonucleotide primer binding sites within the genome (Williams et al., 1990) or from mutations in DNA sequences (either a change in the base sequence or in the number of copies of a specific DNA sequence), including substitution mutations (point mutations), rearrangements (insertions or deletions), or errors in the replication of tandemly repeated DNA (Haliem and Al-Huqail, 2014) due to environmental stress in different ecogeographical regions. Additionally, such changes in DNA configuration may lead to the loss or deletion of DNA bands (non-unique), gain (insertion) of amplified DNA bands (unique), changes

Genetics and Molecular Research 15 (4): gmr.15048916 
in nitrogenous bases, or changes in DNA fragment size, and consequently, different length DNA fragments with high polymorphism that could be very valuable for DNA fingerprinting and the identification of genetic variations among different cumin germplasm accessions. Additionally, DNA polymorphism among cumin germplasm may be due to different levels of ROS induced by harmful abiotic oxidative stresses found within their ecogeographical regions, which may attack covalent bonds in deoxyribose sugars of DNA during replication, causing DNA strands to break or attack DNA bases, especially purines or changes in gene expression, and consequently, oxidative proteins (Sanghera et al., 2013).

The different numbers of gene products amplified by RAPD analysis may contribute to the number and direction of the genome sequences complementary to the nitrogenous base sequences of the primer. In the current study, more amplified DNA products were obtained from cumin accession A-48 than from the other accessions. This may be due to the polyploidazition of genetic materials or chromosomal numbers of cumin subjected to abiotic stress in the ecogeographical region of this accession.

In the present study, distinct variations in the DPPH and $\beta$-carotene-linoleate assays, and in the total phenolic and flavonoid contents were observed among and between 11 cumin accessions. These variations could be explained by high variability in the substances with antioxidant characteristics present in the cumin accessions. This indicates that cumin seeds are a good source of natural antioxidant substances such as flavonoids and phenolic acids, and have high antioxidant potential and oxygen radical scavenging activities, which can delay or inhibit the oxidation of protein and nucleic acids by inhibiting the initiation of oxidizing chain reactions (Debnath et al., 2012). Variations in the levels of total phenol and flavonoids observed in this study indicate that cumin seed extracts of all accessions possess the potential for accumulating phenols and flavonoids.

Variations in the antioxidant potential of cumin seeds may be interpreted as the result of multiple genetic and environmental factors, which affect the production and accumulation of bioactive compounds that form antioxidants (Debnath et al., 2012). Investigation of the antioxidant potential with particular concern of ecological and geographical distribution of plant accessions has become of interest in recent studies (Pisoschi and Negulescu, 2011). Although cumin accessions can exhibit marked variations in antioxidant content owing to their different ecogeographical distribution, clustering based on SDS-PGE and RAPD data was not identical with that based on the antioxidant activity. This may be because these markers have the advantage of directly detecting sequence variation among cumin genotypes and can therefore, bypass the factors that affect antioxidant activity. SDS-PAGE markers can reveal differences in protein-coding genes (expressed), while RAPD markers are distributed throughout the genome (coding and non-coding regions). The genetic interpretation of relation between genetic diversity among cumin accessions and their antioxidant activity that the coding regions (expressed) of the genome are accessible to phenotypic expression and might have resulted in agreement between biochemical traits such as antioxidant activity and genetic variations while non-coding regions are in contrast to this (Debnath et al., 2012).

Cumin accessions with low levels of antioxidants may be exposed to harmful oxidative abiotic stress in their ecogeographical regions leading to the production of cellular ROS, which are toxic and highly reactive with DNA, RNA, and proteins. These may cause damage to the purine and pyrimidine bases and to the deoxyribose backbone, as well as causing changes to gene expression and consequently, the formation of abnormal oxidative proteins (Sanghera et al., 2013). In contrast, extracts from cumin accessions that contain the highest levels of 
antioxidant content can delay, inhibit, or prevent the oxidation of biomolecules like proteins and nucleic acids, and may scavenge free radicals or break the chain reaction due to their redox properties (Dua et al., 2012). This variability in antioxidant levels could lead to distinct polymorphisms in protein and DNA banding patterns among 11 cumin germplasm accessions, which reflected their ecogeographical distribution.

In conclusion, in the present study, SDS-PGE and RAPD markers were able to detect a sufficient degree of genetic polymorphism to enable differentiation of cumin genotypes. This makes these technologies valuable for cultivar identification and for the more efficient choice of parents in current breeding and genetic improvement programs of cumin crop. Each biomarker system used in this study has its own strengths and limitations, making the choice of marker an important decision that represents a compromise between reliability and ease of analysis, and the confidence of its ability to identify polymorphisms. The selection of cumin germplasm accessions based on SDS-PGE and RAPD analyses combined with antioxidant capacity will play an important role in improving environmental friendly cumin cultivars, and in current breeding and genetic improvement programs of cumin as a medicinal spice. The genetic relationships identified by cluster analyses based on SDS-PGE and RAPD data indicated that these two marker techniques were nearly equivalent, but not identical, to that based on the antioxidant activity data. Finally, this study also showed that cumin germplasms are valuable genetic resources for high antioxidant activity and could be a valuable resource when included in a cumin breeding program. Hence, it is recommended that further selection of genotypes/germplasm/accessions/populations with high antioxidant activity using protein and DNA markers would be useful for breeding programs, especially when no other genetic information is available for this plant species.

\section{Conflicts of interest}

The authors declare no conflict of interest.

\section{ACKNOWLEDGMENTS}

The authors would like to extend their sincere appreciation to the Deanship of Scientific Research at King Saud University for funding this research through the Research Group Project \#RGP-231. The authors also wish to express their deep thanks to the Plant Gene Bank; National Agriculture and Animal Resources, Research Centre, Ministry of Environment, Water and Agriculture, Saudi Arabia for providing the cumin seeds.

\section{REFERENCES}

Bahraminejad A, Mohammadi-Nejad G, Kadir MA and Yusop MR (2012). Molecular diversity of cumin (Cuminum cyminum L.) using RAPD markers. AJCS 6: 194-199.

Ben Tamarzizt H, Walker D, Ben Mustapha S, Abdallah D., et al. (2015). DNA variation and polymorphism in Tunisian plum species (Prunus spp): contribution of flow cytometry and molecular markers. Genet. Mol. Res. 14: 18034-18046.

Chaudhary N, Husain SS and Ali M (2014). New Phenolic, triterpenic and steroidal constituents from the fruits of Cuminum cyminum L. J. Pharm. Phytochem 3: 149-154.

Choudhary S, Meena RS, Singh R, Vishal MK, et al. (2015). Analysis of diversity among cumin (Cuminum cyminum) cultivars using RAPD markers. Indian J. Agr. Sci. 85: 56-63.

Debnath SC, Siow YL, Petkau J, An D, et al. (2012). Molecular markers and antioxidant activity in berry crops: Genetic diversity analysis. Can. J. Plant Sci. 92: 1121-1133. http://dx.doi.org/10.4141/cjps2011-240

Genetics and Molecular Research 15 (4): gmr.15048916 
Dua A, Gupta SK, Mittal A and Mahajan R (2012). A Study of Antioxidant Properties and Antioxidant Compounds of Cumin (Cuminum cyminum). IJPBA 3: 1110-1116.

Galani S, Naz F, Soomro F, Jamil I, et al. (2011). Seed storage protein polymorphism in ten elite rice (Oryza sativa L.) genotypes of Sindh. Afric. J. Biot. 10: 1106-1111.

Ghasemi M, Kazemi MH, Yoosefi A, Ghasemi A, et al. (2014). Rapid antidepressant effects of repeated doses of ketamine compared with electroconvulsive therapy in hospitalized patients with major depressive disorder. Psychiatry Res. 215: 355-361. http://dx.doi.org/10.1016/j.psychres.2013.12.008

Haliem EA and Al-Huqail AA (2014). Correlation of genetic variation among wild Trigonella foenum-graecum L. accessions with their antioxidant potential status. Genet. Mol. Res. 13: 10464-10481. http://dx.doi.org/10.4238/2014. December.12.8

Hojilla-Evangelista MP and Evangelista RL (2006). Effects of cooking and screw-pressing on functional properties of Cuphea PSR23 seed proteins. J. Am. Oil Chem. Soc. 83: 713-718. http://dx.doi.org/10.1007/s11746-006-5028-8

Idrees M and Irshad M (2014). Molecular Markers in Plants for Analysis of Genetic Diversity: A Review. Eur. Acad. Res. 11: 1513-1540.

Khoshroo SMR, Khavarinejad R, Baghizadeh A, Fahimi H, et al. (2011). Seed storage protein electrophoretic profiles in some Iranian date palm (Phoenix dactylifera L.) cultivars. Afr. J. Biotechnol. 10: 17793-17804.

Kit YS and Chandran S (2010). A simple, rapid and efficient method of isolating DNA from Chokanan mango (Mangifera indica L.). Afr. J. Biotechnol. 9: 5805-5808.

Kumar OA and Tata SS (2010). SDS-PAGE seed storage protein profiles in chili peppers (Capsicum L.). Not. Sci. Biol. 2: 86-90.

Kumar P, Gupta VK, Misra AK, Modi DR, et al. (2009). Potential of molecular markers in plant biotechnology. Plant Omics J. 2: 141-162.

Laemmli UK (1970). Cleavage of structural proteins during the assembly of the head of bacteriophage T4. Nature 227: 680-685. http://dx.doi.org/10.1038/227680a0

Lim SN, Cheung PCK, Ooi VE and Ang PO (2002). Evaluation of antioxidative activity of extracts from a brown seaweed, Sargassum siliquastrum. J. Agric. Food Chem. 50: 3862-3866. http://dx.doi.org/10.1021/jf020096b

Masoumi SM, Kahrizi D, Rostami-Ahmadvandi H, Soorni J, et al. (2012). Genetic diversity study of some medicinal plant accessions belong to Apiaceae family based on seed storage proteins patterns. Mol. Biol. Rep. 39: 10361-10365. http://dx.doi.org/10.1007/s11033-012-1914-3

Mondini L, Noorani A and Pagnotta MA (2009). Assessing plant genetic diversity by molecular tools. Diversity (Basel) 1: 19-35. http://dx.doi.org/10.3390/d1010019

Nadeem M and Riaz A (2012). Cumin (Cuminum cyminum) as a potential source of antioxidants. Pak. J. Food Sci. 22: 101-107.

Pang PG, Afandi A, Shefiqur R and Kumar SR (2012). Sodium dodecyl sulphate polyacrylamide gel electrophoresis pattern of horse gram seed storage proteins during germination. Int. Res. J. Biol. Sci. 1: 39-50.

Parashar M, Jakhar ML and Malik CP (2014). A review on biotechnology, genetic diversity in cumin (Cuminum cyminum). Int. J. Life Sci. Pharm. Res. 4: 17-34.

Pisoschi MA and Negulescu GP (2011). Methods for total antioxidant activity determination: a review. Biochem. Anal. Biochem. 1: 106-115.

Ravindran C and Naveenan T (2011). Adaptation of marine derived fungus Chaetomium globosum (NIOCC 36) to alkaline stress using antioxidant properties. Process Biochem. 46: 847-857. http://dx.doi.org/10.1016/j.procbio.2010.12.005

Ravindran C, Naveenan T, Varatharajan GR, Rajasabapathy R, et al. (2012). Antioxidants in mangrove plants and endophytic fungal associations. Bot. Mar. 55: 269-279. http://dx.doi.org/10.1515/bot-2011-0095

Rebey IB, Jabri-Karoui I, Hamrouni-Sellami I and Bourgou S (2012). Effect of drought on the biochemical composition and antioxidant activities of cumin (Cuminum cyminum L.) seeds. Ind. Crops Prod. 36: 238-245. http://dx.doi. org/10.1016/j.indcrop.2011.09.013

Rostami-Ahmadvandi H, Cheghamirza K, Kahrizi D and Bahraminejad S (2013). Comparison of morpho-agronomic traits versus RAPD and ISSR markers in order to evaluate genetic diversity among Cuminum cyminum L. accessions. AJCS 7: 361-367.

Sadia M, Malik SA, Rabbani MA and Peaece SR (2009). Electrophoretic characterization and the relationship between some brassica species. Electron. J. Biol. 5: 1-4.

Sanghera GS, Malhotra PK, Sidhu GS, Sharma VK, et al. (2013). Genetic engineering of crop plants for enhanced antioxidants activity. Intern. J. Adv. Res. Tech. 2: 428-458.

Saraswati R, Matoh T, Phupaibul P, Lumpkin T, et al. (1993). Identification of Sesbania species from electrophoretic patterns of seed proteins. Trop. Agr. 70: 282-285.

Genetics and Molecular Research 15 (4): gmr.15048916 
Sharaf-Eldin MA, Al-Tamimi A, Alam P, Elkholy SF, et al. (2015). Genetic relatedness of artichoke (Cynara scolymus L.) hybrids using random amplified polymorphic DNA (RAPD) fingerprinting. Genet. Mol. Res. 14: 18431-18439. http:// dx.doi.org/10.4238/2015.December.23.31

Singh PKR, Panwar N and Bhagyawant SS (2015). Evaluation of genotypic variation using SDS-PAGE. Euro. J. Biol. Biosci. 3: 39-40.

Sliwinska E, Pisarczyk I, Pawlik A and Galbraith DW (2009). Measuring genome size of desert plants using dry seeds. Botany 87: 127-135. http://dx.doi.org/10.1139/B08-120

Srivastava A, Suchita S and Sanchita S (2013). Phytochemical investigation of different plant parts of Calotropis procera. Int. J. Sci. Res. Pub. 3: 1-4.

Williams JGK, Kubelik AR, Livak KJ, Rafalski JA, et al. (1990). DNA polymorphisms amplified by arbitrary primers are useful as genetic markers. Nucleic Acids Res. 18: 6531-6535. http://dx.doi.org/10.1093/nar/18.22.6531

Wilson K and Walker J (2005). Principles and Techniques of Biochemistry and Molecular Biology. Cambridge University Press, Cambridge.

Zhishen J, Mengcheng T and Jianming W (1999). The determination of flavonoids content in mulberry and their scavenging effects on superoxide radicals. Food Chem. 64: 555-559. http://dx.doi.org/10.1016/S0308-8146(98)00102-2

Genetics and Molecular Research 15 (4): gmr.15048916 